\title{
Persepsi Gamers tentang Aktivitas Microtransactions di Virtual Goods Marketplace Itemku.com
}

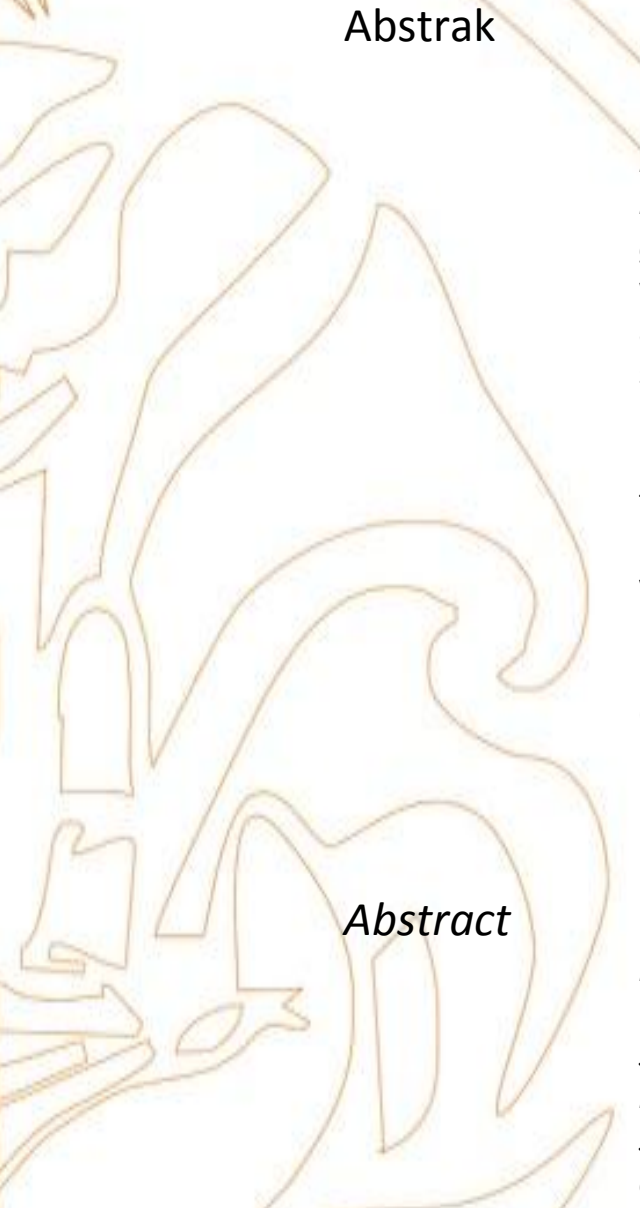

(1) Journal of Strategic Communication Vol. 11,No. 2, Hal. 99-108 Maret 2021

Fakultas Ilmu Komunikasi, Universitas Pancasila

The growth of games as a fast growing industry in Indonesia has made online gaming business lines increasingly developed, so that a business market for buying and selling virtual goods (virtual items in games) is formed in several virtual goods marketplaces such as itemku.com. The formation of the business market on the virtual goods marketplace has created various perceptions to support their gaming activities. This study uses qualitative methods, observation techniques, in-depth interviews and documentation. The theory used is perception. This study will discuss how variables such as sensation, anticipation and interpretation are formed from gamers about how microtransactions are carried out and also associated with CMC (Computer Mediated Communcations) to find out how communication patterns occur in these mictrotransactions. As a result, the majority of gamers have the same perception of microtransactions. Gamers who make virtual goods transactions aim to get satisfaction as well as actualization, virtual items that have more value in the game also trigger to perform microtransactions as part of the pride, and factor of self-existence when doing gaming activities using CMC.

Keywords : Gamers, Microtransactions, Virtual Goods Marketplace.

Pertumbuhan game sebagai sebuah industri yang berkembang pesat di Indonesia telah uat lini bisnis berbasis online gaming kian berkembang, hingga terbentuk pasar marketplace seperti itemku.com. Terbentuknya pasar bisnis pada situs virtual goods memunculkan beragam persepsi para gamers untuk menunjang aktivitas wawancara mendalam dan dokumentasi, Dalam penelitian ini teori yang digunakan adalah teori persepsi. Penelitian ini akan membahas bagaimana variabel-variabel seperti sensasi, antensi dan interpretasi yang terbentuk dari para gamers tentang (Computer Mediated Communcations) untuk mengetahui pola-pola komunikasi yang terjadi dalam mictrotransactions tersebut. Hasilnya, mayoritas gamers memiliki persepsi yang sama terhadap microtransactions. Gamers yang melakukan transaksi virtual goods bertujuan untuk mendapatkan kepuasan juga aktualisasi dalam diri, virtual items yang memilki "value" lebih di dalam game juga menjadi pemicu gamers diri ketika melakukan aktivitas gaming menggunakan CMC.

Kata kunci : Persepsi, Gamers, Microtransactions, Virtual Goods Marketplace. 


\section{PENDAHULUAN}

Di tengah derasnya arus perkembangan industri digital, industri games telah menjadi salah satu industri bisnis yang pesat perkembangannya. Di awal kemunculannya, sebagai sebuah teknologi hiburan, game hanyalah dianggap sebagai hiburan sederhana yang bisa dinikmati oleh kalangan tertentu saja. Namun seiring dengan perkembangan teknologi komputer dan internet, loncatan bagi perkembangan game menjadi sebuah industri yang sangat besar. Game tidak lagi hanya dipandang sebagai sarana hiburan dalam konteks "bermain" saja, namun lebih luas lagi menjadi sebuah ladang bisnis yang menjanjikan, bahkan di beberapa wilayah seperti Amerika dan Eropa, game dapat menjadi mata pencaharian seseorang dan sebuah profesi, yang kemudian dikenal dengan sebutan "gamers".

Di awal kemunculannya, game bisa didapatkan dalam bentuk fisik seperti kaset atau $C D$ yang dipasangkan dengan sebuah mesin video game yang dikenal dengan istilah console seperti Playstation atau Nintendo. Sekarang setiap orang bisa memainkan game dengan siapapun dan dimanapun di seluruh dunia, tidak terbatas ruang dan waktu. Kita bisa bermain game dan berkomunikasi dengan gamers lainnya di seluruh dunia dengan bantuan teknologi komputasi dan koneksi internet. Jenis dari game yang membuat para gamers dapat saling terkoneksi ini di sebut dengan game online.

Istilah game online adalah penggabungan dua suku kata bahasa Inggris yaitu game yang artinya permainan, dan online yang berarti dalam jaringan (daring), yang dimaksud ialah jaringan internet. Game online mulai banyak dikenal publik, khususnya di Indonesia sekitar tahun 2001. Seiring berjalan waktu, game online ini pun banyak diminati oleh pasar Indonesia. Game online memiliki beberapa jenis kategori, beberapa yang cukup popular diantaranya seperti: First Person Shooter (FPS) dan Role Play Game (RPG). FPS merupakan sebuah game yang mengambil sudut pandang gamers yang pertama dalam gambar permainannya, sehingga seolaholah kita sendiri yang berperan sebagai pemain di dalam game tersebut, sementara RPG adalah game yang menjalankan tokoh buatan dengan rangakaian cerita seperti layaknya sebuah film, dan tentunya masih banyak kategori-kategori game online lainnya. Beberapa judul game online yang cukup populer di Indonesia adalah Dota 2,
Counter Strike: Global Offensive (CSGO), Player Unknown's Battle grounds (PUBG), APEX Legenddan Point Blank.

Pesatnya perkembangan industri game ini tentu juga membuka peluang-peluang baru bagi para pelaku bisnis, khususnya pelaku bisnis di dunia digital. Perusahaan-perusahaan yang bergerak sebagai developer game kemudian menciptakan suatu algoritma baru dalam proses penjualan game online untuk mempengaruhi para gamers, di mana game tidak lagi hanya bisa dibeli dalam bentuk fisik saja, melainkan dapat dibeli dalam bentuk nonfisik atau digital (Yusuf, A. 2018).

Salah satu pasar online games yang menyediakan game nonfisik dan digital item yang terbesar dan sangat popular di dunia adalah Steam. Steam merupakan platform distribusi digital games content yang dibuat oleh perusahaan digital bernama Valve Corporation. Steam menawarkan beragam layanan multiplayer online games, termasuk menyediakan pasar jual beli online virtual items untuk para penggunanya, yang dinamakan dengan steam marketplace. Hal itulah yang kemudian dikenal dengan kegiatan microtransactions. Steam adalah sebuah platform digital terbesar untuk permainan video games dalam segmen personal computer basedgames.

Pada tahun 2013, Steam telah memiliki pangsa pasar sekitar $75 \%$. Penjualan melalui Steam mencapai US\$4,3 miliar di tahun 2017, yaitu sekitar $18 \%$ penjualan personal computer based-games secara global. Kemudian pada tahun 2018, layanan Steam ini telah memiliki total pengguna sebanyak 150 juta orang seluruh dunia. Mictrotransactions yang dihadirkan dalam platform Steam ini merupakan model bisnis baru, di mana para penggunanya dapat membeli dan menjual kembali barang virtual.

Perkembangan pasar gamers di Indonesia yang pesat tentunya bukan saja menarik antusiasme para gamers, tapi juga para pelaku bisnis digital. Salah satunya adalah dengan hadirnya sebuah situs dengan nama itemku.com dengan basis e-commerce marketplace yang aktivitasnya adalah membuat pasar jual beli barang virtual dalam game (virtual goods marketplace). Di itemku.com para gamers bisa melakukan microtransactions atau melakukan aktivitas jual-beli virtual items. Jenis virtual items yang dipasarkan di situs tersebut sangat 
beragam, dari berbagai macam jenis game, terutama game-game populer yang paling banyak diminati di Indonesia.

Itemku.com hadir di Indonesia sebagai bentuk atensi mereka terhadap para gamers yang semakin menjamur. Menurut Pokkt, Decision Lab dan Mobile Marketing Association (MMA) yang melakukan studi terkait industri pasar game di Indonesia menyebutkan, jumlah gamers di tanah air mencapai Rp60 juta dan menghabiskan Rp15 triliun untuk belanja kebutuhan di dalam game mereka, virtual items masuk ke dalam salah satu diantaranya. Jumlah tersebut diperkirakan akan meningkat menjadi Rp100 juta pada 2021.

Tidak dapat dipungkiri bahwa industri game juga merupakan industri bisnis, di mana akan selalu bertujuan untuk memperoleh keuntungan besar dengan modal sekecil mungkin. Dengan internet yang semakin mudah diakses, dan dukungan dari platform gaming-nya secara langsung, membuat peluang untuk menerapkan model bisnis ini kian terbuka lebar. Sehingga bukan menjadi suatu keanehan jika peluang ini dimanfaatkan untuk menghadirkan microtransactions dalam sebuah game.

Barang dan fitur yang tersedia oleh transaksi mikro dapat beragam dari kosmetik (seperti pakaian pemain yang bersifat dekoratif) hingga fungsional (seperti senjata dan beberapa barang lainnya) atau yang dikenal dengan istilah "skins". Harga barang yang di jual di steam.com atau di situs virtual goods marketplace seperti itemku.com yang menggunakan transaksi mikro cukup beragam dan memiliki tingkatan dari yang harga sangat murah sampai yang paling mahal, bahkan banyak virtual items yang harganya jauh melebihi harga dari game itu sendiri, terutama virtual items dari game yang paling populer seperti misalnya CSGO dan Dota 2.

Atas dasar permasalahan yang telah dipaparkan, peneliti tertarik untuk meneliti persepsi gamers tentang transaksi mikro di situs penyedia layanan virtual goods marketplace itemku.com (Setiawan, C. A. 2014). Penelitian ini juga bertujuan untuk mengetahui mengapa seorang gamers sampai rela merogoh kocek-nya dalam-dalam untuk barang yang tidak memiliki fisik, melainkan item nonfisik yang hanya dapat dimiliki secara virtual. Oleh karena itu, peneliti mencoba mengungkapkan bagaimana persepsi gamers tentang aktivitas microtransactions yang ditawarkan oleh situs penyedia layanan virtual goods marketplace "itemku.com" dan faktorfaktor apa saja yang mempengaruhi persepsi gamers sehingga melakukan transaksi mikro di situs itemku.com?

Tujuan dari penelitian ini guna mengetahui persepsi para gamers dalam melakukan transaksi gaming virtual goods di itemku.com, faktor yang melandasi para gamers sehingga memperjualbelikan barang-barang nonfisik, serta di mana proses transaksi tersebut menggunakan uang asli layaknya transaksi jual beli pada umumnya.

\section{TINJAUAN PUSTAKA}

\section{Konsep Persepsi}

Penelitian ini akan menggunakan konsep dan teori yang relavan dengan permasalah yang akan diteliti. Menurut Deddy Mulyana dalam bukunya Ilmu Komunikasi: Suatu Pengantar mengatakan bahwa persepsi adalah inti dari komunikasi, sedangkan penafsiran adalah inti dari persepsi, yang identik dengan penyandian-balik (decoding) dalam proses komunikasi (Mulyana, 2005). Persepsi disebut inti komunikasi, karena jika persepsi kita tidak akurat, tidak mungkin kita dapat berkomunikasi dengan baik.

Kenneth et al (Mulyana, 2005) menyebutkan bahwa persepsi terdiri dari tiga aktivitas, yaitu seleksi, organisasi, dan interpretasi. Seleksi sebenarnya mencakup sensasi dan atensi, sedangkan organisasi melekat pada interpretasi, yang dapat didefinisikan sebagai meletakan suatu rangsangan bersama rangsangan lainnya sehingga menjadi suatu keseluruhan yang bermakna. Persepsi meliputi penginderaan (sensasi) melalui alat-alat indra kita (indra peraba, indra penglihat, indra pencium, indra pendengaran, indra pengecap), atensi, dan interpretasi (Mulyana, 2005:181).

Berdasarkan pemaparan di atas maka dapat ditarik tiga unsur yang membentuk persepsi, yaitu:

\section{a. Sensasi}

Sensasi merujuk pada pesan yang di kirimkan ke otak melalui keseluruhan alat indra yang dimiliki oleh manusia. Reseptor indrawi meliputi mata, telinga, hidung, kulit, dan lidah adalah 
penghubung antara otak manusia dan lingkungan sekitar. Makna pesan yang dikirimkan ke otak harus dipelajari, sehingga semua indra itu punya andil bagi berlangsungnya komunikasi manusia. Penglihatan menyampaikan pesan nonverbal ke otak untuk diinterpretasikan. Oleh karena otak menerima dua pertiga persen melalui rangsangan visual. Penglihatan mungkin merupakan indra paling penting. Pendengaran juga menyampaikan pesan verbal ke otak untuk ditafsirkan. Tidak seperti visual yang menuntut mata mengarah pada objek, suara diterima dari semua arah. Penciuman, sentuhan, pengecapan terkadang memainkan peran penting dalam komunikasi lewat bau yang menyengat, jabatan tangan yang kuat, dan rasa air garam di pantai.

\section{b. Atensi}

Atensi merupakan proses di mana sebelum kita merespon atau menafsirkan kejadian atau rangsangan apapun, kita harus lebih dulu memperhatikan kejadian atau rangsangan tersebut. Ini berarti bahwa persepsi mensyaratkan kehadiran suatu objek untuk dipersepsi, rangsangan yang menarik perhatian cenderuang kita anggap lebih penting daripada yang tidak menarik perhatian. Rangsangan seperti itu dianggap penyebab kejadian-kejadian berikutnya (Effendy, 1986).

\section{c. Interpretasi}

Tahap terpenting dalam persepsi adalah interpretasi atas informasi yang kita peroleh melalui salah satu atau lebih indra kita. Namun gamers tidak dapat menginterpretasikan makna informasi yang dipercayai mewakili objek tersebut. Jadi pengetahuan yang kita peroleh melalui persepsi bukan pengetahuan mengenai objek yang sebenarnya, melainkan pengetahuan mengenai bagaimana tampaknya objek tersebut. Interpretasi juga dapat dikatakan sebagai proses subjektif yang menjelaskan persepsi untuk menetapkan maknanya kepada semua objek. Untuk mengartikan makna, orang merancang penjelasan dari apa yang mereka katakan dan lakukan (Nugraha, 2018).

\section{Online Games}

Permainan daring (online games) adalah jenis permainan yang memanfaatkan jaringan komputer. Jaringan yang biasanya digunakan adalah jaringan internet dan yang sejenisnya serta menggunakan teknologi yang ada saat ini, seperti modem dan koneksi kabel. Biasanya permainan daring disediakan sebagai tambahan layanan dari perusahaan penyedia jasa online, atau dapat diakses langsung melalui sistem yang disediakan dari perusahaan penyedia permainan tersebut. Sebuah game online bisa dimainkan secara bersamaan dengan menggunakan komputer yang terhubung ke dalam sebuah jaringan tertentu.

Menurut Andrew Rollings dan Ernest Adams, permainan daring lebih tepat disebut sebagai sebuah teknologi, dibandingkan sebagai sebuah genre permainan; sebuah mekanisme untuk menghubungkan pemain secara bersama, dibandingkan pola tertentu dalam sebuah permainan (Rolling \& Adams, 2006:770). Game online kebanyakan tidak memiliki bentuk fisik seperti kaset CD melainkan berbentuk digital dan diunduh melalui situs atau pasar game. Kebanyakan game online bisa diunduh gratis namun ada beberapa game online yang mengharuskan pemainnya untuk membayar terlebih dahulu sebelum memainkan game dengan menggunakan uang atau digital point yang disediakan oleh situs atau pasar game seperti Steam.

Online game adalah permainan secara online yang biasanya dimainkan lebih dari satu pemain di mana dalam online game individu dapat berinteraksi dengan yang lain, baik dengan individu yang sudah dikenal ataupun belum dikenal (biasanya berkenalan sebatas chat online dan hampir tidak pernah bertemu). online game sendiri hanya bisa dimainkan menggunakan internet, sehingga jika tidak ada internet maka online game tidak dapat dimainkan. Online game merupakan perpaduan dari grafis yang canggih yang memberikan hiburan dan tantangan sendiri, pesan text atau chatting untuk berkomunikasi dan menggunakan unsur server dan client.

Server merupakan jaringan yang diberikan untuk menyediakan pelayanan administrasi permainan, sedangkan client sebutan untuk pemain. Pada akhirnya online game menjadi tempat di mana interaksi dan kegemaran yang sama untuk individu-individu (Pratiwi, E. 2017). Ada pembagian jenis-jenis online game seperti MMORPG (Massively Multiplayer online RolePlaying Game), MMORTS (Massively Multiplayer online Real Time Strategy), MMOFPS (Massively Multiplayer online First Person Shooter) (Nugraha, 2018). 
Sementara itu, online games yang paling diminati tahun 2018 adalah CSGO (Counter Strike: Global Offensive) kemudian disusul oleh Dota 2 yang sebelumnya menjadi peringkat pertama sebagai game yang paling sering dimainkan di Steam. Dari game-game tersebut, memiliki sistem transaksi mikro dan sebagian harus dimainkan secara online untuk mengakses beberapa fitur seperti multiplayer atau bermain bersama teman.

\section{Microtransactions}

Microtransactions atau transaksi mikro merupakan model bisnis di mana pengguna dapat membeli barang virtual melalui pembayaran mikro. Transaksi mikro seringkali digunakan dalam permainan gratis untuk menyediakan sumber pendapatan bagi para pengembang. Sementara transaksi mikro merupakan hal yang umum pada pasar aplikasi ponsel, mereka juga tersedia pada platform komputer seperti Steam pada Valve.

Microtransactions yang baik adalah yang dibuat benar-benar terlihat optional, atau harus dibeli jika pemain tertarik untuk membelinya. Keberadaan microtransactions ini tidak akan mempengaruhi gameplay sama sekali dan kamu selalu bisa mainkan game tersebut tanpa harus mengeluarkan sepeser pun.

Pembelian item dan game dengan microtransactions bisa dilakukan dengan uang virtual yang disediakan oleh game, uang virtual sendiri adalah sebuah jenis uang digital tak biasa yang dikeluarkan dan dikendalikan oleh para pengembangnya (Bitcoin adalah sebuah pengecualian), dipakai dan diterima oleh para anggota komunitas virtual spesifik. Financial Crimes Enforcement Network (FinCEN), sebuah biro Keuangan AS, mendefinisikan mata uang virtual sebagai sebuah perwakilan digital dari nilai yang dikeluarkan oleh sebuah bank sentral atau sebuah otoritas publik, maupun kebutuhan yang ditujukan untuk mata uang fiat, namun diterima oleh orang-orang hukum atau alami sebagai alat pembayaran dan dapat ditransfer, disetor atau diperdagangkan secara elektronik. Sebaliknya, mata uang digital yang dikeluarkan oleh bank sentral diartikan sebagai "mata uang digital bank sentral" (Dubois, 2018).

\section{Virtual Goods/Virtual Items}

Virtual goods atau yang lebih dikenal dengan istilah virtual items merupakan salah satu bentuk aktivitas microtransactions, khususnya di dalam konteks industri game online. Virtual items adalah benda atau uang nonfisik yang dibeli untuk digunakan dalam komunitas online atau game online. Item yang dibeli atau dikirimkan melalui dunia virtual pada dasarnya adalah properti yang sifatnya virtual. Item virtual pada game online bisa berupa kustomisasi avatar, basis, ataupun karakter pemain yang dibeli menggunakan uang asli.

Penggunaan item virtual pada game online merupakan sebuah keharusan yang tidak terelakkan. Hal ini berdampak langsung pada peningkatan industri terkait. Industri game online di seluruh dunia, khusus untuk virtual item saja, diperkirakan mencapai nilai profit UD\$15 milyar (Setiawan, 2014). Pesatnya pertumbuhan industri virtual item pada game online mengindikasikan tingginya tingkat transaksi pemain untuk membeli virtual item.

Virtual items adalah suatu peralatan yang memberikan manfaat yang dikumpulkan atau dibeli oleh seorang gamers. Item bisa berupa kosmetik pelengkap seperti armor, tas, sepatu, senjata dan lain sebaginya (yang kemudian disebut dengan istilah "skins") yang banyak ditemukan di dalam game, tergantung dari jenis game yang dimainkan, contoh game yang memilki variasi item adalah game dengan genre FPS (First Person Shooter) dan RPG (Role Play game).

\section{Itemku.com sebagai Situs Penyedia Virtual Goods Marketplace}

Itemku.com adalah situs belanja daring berjenis pelanggan yang berfokus pada transaksi produk virtual, seperti item, akun, dan mata uang permainan video serta berbagai jenis voucher beragam game online. Situs itemku.com ini secara umum masuk dalam kategori e-commerce, namun lebih spesifik tergolong virtual goods marketplace. Dalam bertransaksi, pengguna itemku.com umumnya memanfaatkan fitur transaksi yang ada di dalam game. Itemku.com berperan sebagai pihak ketiga, atau eskro, yang bertanggungjawab menampung dana dari pihak pembeli hingga pihak penjual selesai mengirimkan pesanan. 
Peluang ekspansi itemku.com memang terbilang lebih besar jika dibandingkan dengan online marketplace lain. Salah satu alasannya adalah karena mereka sama sekali tidak memerlukan uluran tangan dari penyedia jasa logistik layaknya marketplace yang berkutat dengan produk-produk fisik. Ingat, barangbarangnya bisa dikatakan tidak berwujud, dan hanya bisa dinikmati jika gamers memainkan game yang bersangkutan.

Metode pembayaran yang disediakan oleh itemku.com diantaranya bisa dilakukan dengan kartu kredit atau debet, Paypal, dan yang paling populer digunakan di Indonesia adalah melalui OVO. OVO adalah sebuah aplikasi smart yang memberikan layanan pembayaran dan transaksi secara online (OVO Cash). Anda juga bisa berkesempatan untuk mengumpulkan point setiap kali melakukan transaksi pembayaran melalui OVO.

Secara umum, OVO Cash dapat digunakan untuk berbagai macam pembayaran yang telah bekerja sama dengan OVO menjadi lebih cepat. Sedangkan OVO Points adalah loyalty rewards bagi yang melakukan transaksi menggunakan OVO Cash di merchant rekanan OVO. Untuk OVO Points sendiri, dapat ditukarkan dengan berbagai penawaran menarik hingga ditukarkan dengan transaksi di merchant rekanan OVO. OVO menawarkan kemudahan transaksi tanpa mengharuskan nasabahnya membawa cash terlalu banyak. Salah satunya cukup dengan menunjukkan aplikasi OVO yang didalamnya terdapat saldo cash maupun point.

Hal tersebut tentu merupakan salah satu bentuk dari merketing communication strategy yang diterapkan oleh pihak itemku.com guna memperkuat branding pada situs mereka sebagai one-stop platform untuk memperoleh semua kemudahan dalam akses jual-beli gaming virtual goods dalam satu platform (Dubois, 2018). Lalu kemudian strategic communication adalah tentang "how communication can add to the process of translating broadroom strategy to front-line execution, as well as the ability communications to support strategy development." Penjelasan ini tidak lebih dari "bridging activity" untuk tidak mengatakan bahwa komunikasi hanyalah sekedar interpreter, translator dan supporter saja (Estaswara, 2020:3).
Itemku.com didirikan pada tahun 2014 di Jakarta sebagai anak usaha dari PT Five Jack, sebuah perusahaan rintisan asal Korea Selatan. Sebelum menjadi situs perdagangan elektronik, itemku.com memulai usahanya sebagai platform iklan baris sekaligus perbandingan harga item gim. Di awal operasinya, itemku berfokus pada transaksi jual-beli mata uang permainan video berjenis MMORPG. Hingga 2018, itemku.com telah melayani transaksi produk virtual pada lebih dari 40 permainan video, termasuk Dota 2, Mobile Legends: Bang Bang, dan Counter Strike: Global Offensive. Selain itu, itemku.com juga memungkinkan penggunanya untuk memperjualbelikan kode voucher, baik yang berkaitan dengan permainan video maupun yang lebih umum seperti pulsa dan kuota internet.

\section{Computer-Mediated Communication (CMC)}

Computer-Mediated Communication (CMC) adalah jenis-jenis program aplikasi yang digunakan untuk melakukan komunikasi antara dua orang atau lebih untuk berinteraksi melalui komputer yang berbeda dan berada di tempat yang berbeda pula. Intinya adalah bagaimana dua orang atau lebih dapat berkomunikasi satu dengan lainnya dengan menggunakan alat pendukung komputer melalui program aplikasi yang ada pada komputer tersebut CMC dapat menyebabkan bermacam perubahan terkait bagaimana manusia dapat berkomunikasi satu sama lain, dan juga mempengaruhi pola komunikasi serta jaringan sosial mereka misalnya (Fulk \& Collins-Jarvis, 2001). Dengan kata lain, teori CMC ini mengarahkan pada efek sosial.

CMC berbeda dari komunikasi tatap muka langsung. CMC membatasi pada level sinkronisasi dari interaksi, yang memungkinkan terjadinya reduksi di dalam interaksi. Lebih jauh lagi, CMC dapat mengatasi penjajahan atas jarak dan waktu (Rice \& Gattiker, 2001).

Konsep CMC ini merupakan salah satu bentuk dari New Media, yang berkaitan dengan media dalam melakukan transaksi virtual. Hadirnya media sosial adalah bentuk dari media baru, yang telah dikembangkan sejak tahun 1980-an hingga saat ini. Hal ini menjadi sebuah perubahan pada konsep media, di mana media tidak lagi mass melainkan dapat menjadi keperluan atau pencapaian dan jangkauan yang sangat pribadi. Konsep media baru mengemukakan konsep interaksi dari informasi pribadi. Media baru yang akan dibahas pada penelitian ini adalah media 
sebagai perangkat teknologi komunikasi yang perangkatnya memiliki ciri mirip dengan lainnya dan memiliki karakter digitalisasi bagi penggunanya untuk berkomunikasi (McQuail, 2010, Ridwan, 2019)

Konsep penting yang ada dalam teori ini adalah presence, menggambarkan bagaimana kondisi psikologis di mana obyek virtual yang dibentuk oleh komputer dan diperlakukan seperti obyek nyata. Selain itu juga ada konsep social presence, yaitu kondisi di mana aktor sosial mendapatkan pengalaman sesuai dengan isyarat atau lambang-lambang sosial yang terdapat dalam berbagai media komunikasi.

\section{METODE}

Metode yang digunakan dalam penelitian ini adalah penelitian kualitatif. Moleong (2007) mendifinisikan penelitian kualitatif adalah penelitian yang bermaksud untuk memahami fenomena tentang apa yang dialami oleh subjek secara holistik, dengan cara mendeskripsikan dalam bentuk kata-kata dan bahasa, pada suatu konteks khusus yang alamiah. Selain itu, menurut Creswell (1998) penelitian kualitatif adalah metode untuk memahami makna dan mengeksplorasi sejumlah individu maupun sekelompok individu yang berasal dari masalah sosial atau kemanusiaan. Penelitian ini menggunakan jenis penelitian kualitatif dalam mengumpulkan data dan menganalisis data menggunakan pendekatan fenomenologi. (Fitwiethayalisyi, 2015).

Teknik pengambilan sampel yang digunakan adalah nonprobability sampling. Nonprobability sampling adalah teknik pengambilan sampel yang tidak memberikan peluang atau kesempatan sama bagi setiap unsur atau anggota populasi, lebih tepatnya teknik pengambilan sampel yang digunakan dalam penelitian ini adalah purposive sampling.

Purposive sampling adalah teknik pengambilan sampel sumber data dengan pertimbangan tertentu. Pertimbangan tertentu ini misalnya orang tersebut yang dianggap paling tahu tentang apa yang kita harapkan, atau mungkin sebagai penguasa sehingga akan mempermudah peneliti menjelajahi objek, situasi sosial yang diteliti (Sugiyono,2017:218).
Penelitian kualitatif dijadikan metode penelitan karena data dan informasi yang didapat tidak berasal dari statistik dan bentuk hitungan lainnya, tetapi tentang kehidupan, perasaan informan, riwayat hidup dan perilaku seseorang (Ardianto, 2016).

\section{HASIL DAN PEMBAHASAN}

Hasil penelitian yang didapat oleh peneliti berdasarkan hasil wawancara kepada delapan orang informan. Informan dalam penelitian ini adalah para gamers yang melakukan aktivitas microtransactionsdan tentunya sudah memiliki akun di situs itemku.com, baik selaku penjual, pembeli, maupun keduanya.

Sensasi Gamers tentang Aktivitas Microtransactions di Situs Virtual Goods Marketplace Itemku.com

Sensasi adalah tahap pertama dalam stimuli mengenai alat indra. Sensasi yang artinya pengindraan, yang menghubungkan organisme dengan lingkungan (Pratiwi, 2017). Sensasi di sini adalah tahap gamers pertama kali mengetahui tentang microtransactions di pasar game Steam. Setelah peneliti melakukan wawancara kepada informan, dapat disimpulkan bahwa kebanyakan dari gamers mengetahui microtransactions dari teman di game ataupun melalui platform digital lain seperti youtube.com.

Dalam penelitian ini juga ditemukan bahwa kesan pertama yang didapatkan gamers saat melakukan microtransactions di situs itemku.com cukup positif karena mereka merasa puas dengan item yang diperjualbelikan. Contohnya untuk jenis item berupa skin beberapa game populer, seperti CSGO dan Dota 2, di mana market yang tercipta dalam aktivitas jual-beli skin di itemku.com terbilang sangat aktif. Informan berpendapat bahwa menjual atau membeli skin di itemku.com cenderung lebih cepat prosesnya dibandingkan dengan membeli di virtual goods marketplace utamanya sebagai developer game tersebut, yaitu di steam.com.

Menurut Agung, selaku informan yang sering melakukan transaksi di situs itemku.com, sensasi yang dirasakan oleh para gamers ketika melakukan aktivitas microtransactions dan memiliki virtual items di dalam akun game mereka adalah rasa bangga dan lebih percaya 
diri. Terutama ketika mereka bermain bersama rekan satu tim, saling menunjukkan virtual items mereka dan membahasnya melui "teamspeak" (virtual chat) di dalam game.

Dari observasi yang dilakukan oleh peneliti juga menemukan bahwa ada perbedaan harga item yang cukup signifikan di itemku.com dibandingkan dengan di steam.com, contohnya salah satu item berupa skin game CSGO "butterfly knife" di itemku.com yang perbedaan harganya bisa mencapai $30-40 \%$ dibandingkan dengan harga di steam.com sebagai developer dari game tersebut.

\section{Atensi Gamers tentang Aktivitas Microtransactions di Situs Virtual Goods Marketplace Itemku.com}

Atensi atau perhatian adalah pemrosesan secara sadar sejumlah kecil dari sejumlah besar informasi yang tersedia. Informasi didapatkan dari pengindraan, ingatan maupun proses kognitif lainnya. Proses atensi membantu efisiensi penggunaan sumberdaya mental yang terbatas yang kemudian akan membantu kecepatan reaksi terhadap rangsangan tertentu.

Menurut Arsyi Bahari selaku informan yang sering melakukan transaksi di situs itemku.com, mengatakan bahwa faktor yang menarik perhatian gamers sehingga melakukan microtransactions di situs itemku.com adalah karena itemku.com menawarkan kemudahan dalam bertransaksi, yang bisa dilakukan dengan banyak cara pembayaran. Gamers memiliki pilihan yang beragam untuk dapat menjual maupun membeli item-item game guna mencapai kepuasan atau kebutuhan dalam bermain game. Untuk melakukan transaksi, gamers tidak perlu saling bertemu dan bahkan bisa diakses langsung melalui smartphone atau komputer. Pilihan metode pembayaran yang juga sangat variatif, seperti pembayaran dengan kartu kredit, kartu debit dan juga dompet digital seperti OVO, GoPay, ataupun Dana.

Kemudian, dari hasil wawancara, peneliti mendapatkan atensi terbesar gamer terhadap aktivitas microtransactions di situs itemku.com adalah dengan adanya fitur keamanan dalam bertransaksi. Itemku.com sebagai situs virtual goods marketplace juga menjadi pihak ketiga dalam semua transaksi yang terjadi di situs itemku.com. Jadi tidak ada proses direct transfer (transfer secara langsung) antara penjual dan pembeli dalam setiap transaksi jual-beli. Semua distribusi dana harus melalui rekening itemku.com sebagai pihak ketiga (perantara transaksi), sehingga hal ini sangat mengurangi potensi terjadinya penipuan dalam bertransaksi.

\section{Interpretasi Gamers tentang Aktivitas Microtransactions di Situs Virtual Goods Marketplace Itemku.com}

Interpretasi atau penafsiran adalah proses komunikasi lisan atau gerakan antara dua atau lebih pembicara yang tak dapat menggunakan simbol-simbol yang sama, baik secara simultan (dikenal sebagai interpretasi simultan) atau berurutan (dikenal sebagai interpretasi berurutan). Menurut definisi, interpretasi hanya digunakan sebagai suatu metode jika dibutuhkan.

Menurut Rizki Irawan selaku informan yang sering melakukan transaksi di situs itemku.com, apabila suatu game memiliki tingkat populeritas yang tinggi dan memilki jumlah pemain yang sangat besar, maka akan meningkatkan antusisasme para gamers. Tingkat kompetitif para gamers dalam game tersebut juga akan semakin tinggi.

Dari pernyataan tersebut peneliti menghubungkan dengan hasil observasi yang di lakukan di mana strategi yang digunakan oleh marketing suatu game salah satunya adalah dengan mengadakan event turnamen game esports tahunan. Dengan adanya turnamen tahunan tersebut tentunya secara tidak langsung akan meningkatkan populeritas yang berujung pada meningkatnya aktivitas microtransactions item-item game di situs itemku.com.

\section{Persepsi Gamers tentang Aktivitas Microtransactions di Situs Virtual Goods Marketplace Itemku.com}

Setelah peneliti melakukan wawancara observasi dan dokumentasi ditemukan bahwa kebanyakan gamers memiliki pengalaman yang sangat baik dan menarik, gamers berpersepsi bahwa sistem microtransactions sangat menguntungkan, baik bagi mereka sebagai konsumen atau developer, sebagai orang yang mengembangkan game-nya, serta steam.com sebagai wadah bertransaksi antara games dan developer. Bagi gamers, jual beli game sekarang sudah sangat mudah dan aman dari pada harus bertemu langsung, hargaharga game yang ditawarkan di steam.com sangat kompetitif ditambah juga dengan diadakannya diskon besar dua kali setahun 
menjadi daya tarik tersendiri yang sulit dilakukan oleh pasar game lain.

Dari hasil observasi dan wawancara yang dilakukan peneliti ditemukan bahwa item-item game yang paling banyak diperjualbelikan di situs itemku.com adalah item game CSGO dan Dota 2, di mana masing-masing game tersebut memilki fitur microtransactions bahkan dari pihak developer-nya. Jenis virtual items seperti skins CSGO dan Dota 2, dalam aktivitas microtransactions pada game-game tersebut hanyalah sebatas kosmetik dan estetika penampilan saja, tidak berpengaruh pada performa dalam game tersebut.

Di sini dapat dilihat bahwa populiritas game menjadi salah satu faktor yang menyebabkan gamers ingin melakukan aktivitas microtransactions, karena semakin populernya sebuah game akan berbanding lurus dengan jumlah orang yang bermain, yang tentunya akan berpengaruh pada aktifnya market jual-beli virtual items dari game tersebut.

Peneliti juga menemukan bahwa eksistensi diri menjadi salah satu faktor bagi gamers dalam melakukan aktivitas microtransactions di itemku.com, ketika seorang gamers memiliki items berupa skins premium atau berbayar yang berbeda dari gamers lain yang kebanyakan menggunakan free skins (skins bawaan gratis dalam game), akan muncul kebanggan tersendiri dan merasa diakui atau ditakuti lawan di dalam game. Hal ini diperkuat oleh pernyataan Deri Alfaridzi selaku informan yang mengatakan bahwa salah satu faktor yang menjadi alasan kenapa gamers melakukan aktivitas microtransactions adalah karena keinginan untuk diakui oleh lingkungannya, di mana lingkungan yang dimaksud di sini adalah lingkungan pertemanan di dalam game.

Faktor selanjutnya menjadi penyebab gamers mau melakukan aktivitas microtransactions ialah kepuasan yang dirasakan ketika mereka mendapatkan item berupa skins atau virtual items lain yang mereka inginkan. Dengan memiliki suatu items di game populer, terlebih jika items tersebut memilki harga yang mahal, tentunya dapat menjadi kebanggan tersendiri dan dapat meningkatkan rasa percaya diri ketika bermain game. Lalu, ketika mereka bermain bersama rekan satu tim, saling menunjukan virtual items milik mereka dan membahasnya melalui "teamspeak" (virtual chat) di dalam game. Hal tersebutlah yang merupakan salah satu pola komunikasi dalam Computer-Mediated Communication (CMC), di mana pola komunikasi yang terbentuk secara simultan akan membentuk persepsi. Para gamers pun rela merogoh koceknya hanya untuk penampilan estetika saja, demi mendapatkan pride dari rekan-rekannya ketika bermain bersama, di mana para gamers menyebutnya dengan istilah "MaBar" (main bareng).

Sebagian gamer juga beranggapan bahwa game dan item-item di dalamnya sebagai suatu bentuk investasi di mana harga virtual items pada game-game populer seperti CSGO \& Dota 2 bisa berubah kapan saja tergantung dari kelangkaan virtual items tersebut. Para gamers menganggap bahwa suatu hari mereka bisa menjual kembali virtual items mereka di situs itemku.com dengan mudah karena mereka menilai bahwa pasar virtual items di Indonesia sudah terbentuk dan bahkan animonya sangat besar.

\section{SIMPULAN}

Microtransactions memilki bentuk transkasi yang identik dengan transaksi pada umunya, yang membedakan ditransaksi mikro barang yang dijual, tidak memilki fisik melainkan bersifat virtual atau digital dan uang yang digunakan adalah uang virtual yang telah di konversi dari mata uang asli. Proses jual beli dilakukan di situs itemku.com sebagai situs penyedia layanan virtual goods marketplace.

Kemudahan dan keamanan sistem bertransaksi yang dihadirkan oleh situs itemku.com yang menjadi fokus atensi utama dari para gamers. Beragam alternatif metode pembayaran yang ditawarkan itemku.com dan keamanan transaksi yang dijamin oleh pihak itemku.com selaku perantara transaksi membuat para gamers merasa tertarik untuk melakukan aktivitas microtransactions di itemku.com.

Selanjutnya interpretasi gamers terhadap aktivitas microtansactions di situs itemku.com adalah bahwa apabila suatu game memiliki tingkat populeritas yang tinggi dan memilki jumlah pemain yang sangat besar, maka akan meningkatkan antusiasme para gamers. Tingkat kompetitif para gamers dalam game tersebut 
juga akan semakin tinggi, yang tentunya akan berpengaruh pada aktivitas microtransactions.

Persepsi dari para gamers adalah bahwa value dari virtual items dianggap bisa menjadi sebuah nilai investasi. Semakin langka virtual items tersebut, akan membuat nilai jualnya semakin tinggi. Dengan terbentuknya ekosistem yang besar pada sebuah game, maka pasar yang terbentuk pun akan semakin luas. Virtual items pada game-game populer seperti CSGO \& Dota 2 sangat diminati oleh para gamers dan menjadi virtual items yang paling sering dicari dan paling tinggi penjualannya di situs itemku.com. Atas pertimbangan itulah para gamers memiliki keinginan untuk melakukan aktivitas microtransactions di situs penyedia layanan virtual goods marketplace itemku.com.

\section{DAFTAR PUSTAKA}

Adam Ernest Dan Rollings Andrew. (2006). Fundamentals Of Game Design. Prentice Hall. Yogyakarta: Graha IImu.

Ardianto, E. (2016). Metodologi Penelitian Untuk Public Relations Kuantitatif dan Kualitatif. Bandung: Penerbit Simbiosa Rekatama Media.

Creswell, J. W. (1998). Qualitative Inquiry and Research Design, Choosing Among Five Traditions. California: Sage Publication.

Deddy, M. (2005). Ilmu Komunikasi, Suatu Pengantar, Bandung: Penerbit Remaja Rosda Karya.

Dubois, D. (2018). Nickel and Dimed: Why Microtransactions Are Ruining Video Games.

Effendy, O. U. (1986). Dimensi-Dimensi Komunikasi, Bandung: Alumni.

Estaswara, H. (2020). Memaknai Strategic Communication. CoverAge, Vol 11(1).

Fitwiethayalisyi. (2015). Metode Pengumpulan Data Kualitatif, Blog, diakses pada tanggal 25 April 2020. https://fitwiethayalisyi.wordpress.com/teknol ogi-pendidikan/penelitian-kualitatif-metodepengumpulan-data/

Fulk, J. \& Collins-Jarvis, L. (2001). Wired meetings: Technological Mediation of Organizational Gatherings, Newbury Park, CA: Sage.
McQuail, D. (2010). McQuail's Mass Communication Theory. Netherlands: SAGE Publications, Ltd.

Moleong, L. J. (2007). Metode Penelitian Kualitatif. Bandung: Remaja Rosda karya.

Nugraha, P.A. (2018). Persepsi komunitas gamers Terhadap Game online, studi deskriptif tentang komunitas gamers, Jurnal.

Pratiwi, E. (2017). Perilaku Interpersonal Pecandu game online, Skripsi.

Rice, R.E. \& Gattiker, U.E. (2001). New media and organizational structuring.

Ridwan, Q. U. (2019). Analisis Video Musik Virtual Akun Komunitas @Indomusikgram di Media Sosial Instagram, CoverAge, 9(2).

Setiawan, C. A. (2014). Pola Interaksi Antara Gamers dalam Game Online,Skripsi.

Sugiyono. (2017). Metode Penelitian Kuantitatif, Kualitatif dan R\&D. Bandung: Penerbit Alfabeta.

Yusuf, A. (2018). Jual beli game Online dalam Perspektif Hukum Islam, Skripsi. 